\title{
MODEL PENGENDALIAN ALAMI PENYAKIT EMBUN JELAGA OLEH JAMUR CAPNADIUM SP PADA TANAMAN CENGKEH MENGGUNAKAN KUMBANG HELM CYCLONEDA SPP SEBAGAI PREDATOR KUTU DAUN (COCCOUS VIRIDIS GREEM)
}

\author{
Sudirman ${ }^{1}$, R. Ratianingsih², dan J. W. Puspita ${ }^{3}$ \\ Program Studi Matematika Jurusan Matematika \\ Fakultas Matematika dan IImu Pengetahuan Alam Universitas Tadulako \\ Jalan Soekarno-Hatta Km. 09 Tondo, Palu 94118, Indonesia. \\ 1sudirmanfelisfuzy13@gmail.com, 2Ratianingsih@yahoo.com, 3Juni.wpuspita@yahoo.com
}

\begin{abstract}
ABSTARCT
Soot dew disease is one of the clove plant diseases caused by fungi Capnadium $s p$. fungus Capnadium spliving on filth of aphids Coccous Viridis Green. The fungus is spread by vectors of black ants that exist on a clove vulnerable. To control the disease naturally, people utilize the helmet beetles Cycloneda spp as a pest predator of aphids Coccous Viridis Green. The mathematical models that represent the natural control of the disease was adapted from the SI model. The model provides 9 exiting critical points which describes the state of the system. The results of the stability analysis of the critical points using the method of Linearization and Routh-Hurwitz shows that there are 4 disease-free critical points such that the solution can be maintained in the neighbourhood of the critical points. All endemic critical points are unstable such that the solution will leave the critical points. Simulation at the endemic critical points indicates the existence of helmet beetles Cycloneda spp population that able to suppress the spread of this disease by preying aphids Coccus Viridis Green.
\end{abstract}

Keywords : Dew Soot, Helmet Beetles, Aphids, Mathematical Models.

\section{ABSTRAK}

Penyakit embun jelaga adalah salah satu penyakit pada tanaman cengkeh yang disebabkan oleh jamur Capnadium $s p$. Jamur Capnadium sp hidup dari kotoran hama kutu daun Coccous Viridis Green. Jamur tersebut disebarkan oleh vektor semut hitam pada cengkeh rentan. Pengendalian penyakit ini dilakukan secara alami dengan memanfaatkan kumbang helm Cycloneda spp sebagai predator hama kutu daun Coccous Viridis Green. Model matematika yang merepresentasikan pengendalian alami penyakit ini diadaptasi dari model SI. Model tersebut memberikan 9 titik kritis eksis yang menggambarkan keadaan sistem. Hasil dari analisa kestabilan sistem di titik kritis menggunakan metoda Linearisasi dan Routh-Hurwitz memperlihatkan 4 titik kritis bebas penyakit adalah stabil sehingga solusi sistem dapat dipertahankan menuju titik kritis. Semua titik kritis endemik tidak stabil sehingga solusi sistem akan meninggalkan titik kritis. Simulasi pada titik kritis endemik menunjukkan eksistensi populasi kumbang helm Cycloneda spp mampu menekan penyebaran penyakit ini dengan cara memangsa hama kutu daun Coccus Viridis Green.

Kata Kunci : Embun Jelaga, Kumbang Helm, Kutu Daun, Model Matematika. 


\section{PENDAHULUAN}

Tanaman cengkeh yang dikenal dengan nama latin Syzigium Aromaticum merupakan tanaman asli Indonesia yang berasal dari Kepulauan Maluku. Tanaman Cengkeh di Indonesia menjadi salah satu komoditi perkebunan yang penting untuk bahan baku industri dan menjadi sumber pendapatan bagi petani. Cengkeh memiliki banyak manfaat, selain sebagai rempah-rempah, juga sebagai bahan obat-obatan (obat gigi, obat radang, obat pernapasan, dan baik untuk kesehatan jantung), bahan baku rokok kretek, parfum, pengawet makanan, dan biopestisida. Berkembangnya industri rokok kretek pada tahun 1930-an serta tingginya nilai manfaat yang dimilikinya mengakibatkan kebutuhan cengkeh semakin meningkat (Mariana, 2013).

Meningkatnya areal pertanaman cengkeh diikuti oleh peningkatan masalah yang disebabkan oleh hama dan penyakit. Salah satu penyakit penting yang menyerang tanaman cengkeh (Syzigium Aromaticum) yaitu penyakit embun jelaga yang disebabkan oleh jamur Capnadium sp. Penyebab tidak langsung terjangkitnya penyakit ini adalah adanya koloni kutu daun (Coccus Viridis Green) yang berperan sebagai hama dengan cara menyerang daun merusak ranting dan pada kondisi parah dapat menyebabkan kematian pada tanaman cengkeh. Kutu daun (Coccus Viridis Green)tersebut sekaligus berperan dalam penyediaan makanan bagi jamur Capnadium $s p$ melalui kotorannya yang disebut sebagai embun madu (Mariana, 2013). Menurut (Indriati dkk, 2007) Penurunan produksi tanaman cengkeh akibat jamur Capnadium sp dapat mencapai 33,68\% - 50\%.

Jamur Capnadium sp disebarkan ke seluruh daun cengkeh oleh vektor semut hitam yang juga ikut menjadikan embun madu (kotoran kutu daun) sebagai sumber makanan karena mengandung glukosa. Pengendalian penyakit embun jelaga bergantung pada pengendalian kutu daun (Coccus Viridis Green) karena jamur Capnadium sp hidup dari cairan (embun madu) yang dikeluarkannya (Panggalo, 2014). Selain itu, embun madu tersebut merupakan alasan berkumpulnya banyak vektor semut hitam. Kumbang helm Cycloneda spp merupakan musuh alami yang paling ampuh terhadap kutu daun (Coccus Viridis Green) sehingga dapat dimanfaatkan untuk pengendalian penyakit ini (Ernawati, dan Yuniarti, 2014).

Penelitian ini mengkaji model matematika pengendalian alami penyebaran penyakit embun jelaga yang dibangun berdasarkan fakta-fakta serta asumsi-asumsi yang ada melalui pengadaptasian dari model SI (Suscaptible Infective). Selanjutnya dilakukan analisa kestabilan terhadap model matematika di sekitar titik kritis yang merepresentasikan kondisi bebas penyakit dan endemik menggunakan metode Linearisasi dan Routh-Hurwitz. Analisis terhadap model matematika pengendalian alami penyakit embun jelaga ini dapat dijadikan pembenaran terhadap potensi kumbang helm Cycloneda spp dalam pengendalian penyebaran penyakit tersebut pada tanaman cengkeh. 


\section{METODE PENELITIAN}

Pemodelan Matematika adalah proses mengkonstruksi suatu fenomena alam yang terjadi didalam kehidupan sehari-hari dan diformulasikan ke dalam masalah matematika yang selanjutnya di sebut sebagai model matematika. Sehingga dapat dilakukan pendekatan solusi matematika untuk memperoleh suatu penyelesaian masalah nyata yang dibangun dari model matematika tersebut.

Pada penelitian ini, model matematika dari dinamika pengendalian alami penyakit embun jelaga dilakukan dengan menganalisa kestabilan disekitar titik kritis yang ditentukan oleh nilai eigen dari akar-akar polinomialnya.

Jika $A$ adalah suatu matriks $n x n$ maka sebuah vektor tak nol $\bar{x}$ pada $R^{n}$ disebut vektor eigen dari $A$ jika $A \bar{x}$ merupakan suatu penggandaan skalar dari $\bar{x}$, yakni $A \bar{x}=\lambda \bar{x}$.

Skalar $\lambda$ disebut nilai eigen dari $A$, dan $\bar{x}$ disebut suatu vektor eigen dari matriks $A$ yang berpadanan terhadap $\lambda$. Nilai eigen dari matriks $A_{n x n}$ dapat diperoleh dengan cara menuliskan kembali persamaannya sebagai berikut :

$(A-\lambda I) \bar{x}=0$.

Agar supaya $\lambda$ menjadi nilai eigen, maka harus ada pemecahan tak nol dari persamaan ini. Persamaan tersebut akan memiliki pemecahan yang tak nol jika dan hanya jika $\operatorname{Det}(A-\lambda I)=0$.

(Anton, 1992:278)

Kriteria kestabilan titik kritis ditentukan oleh setiap nilai eigen dari matriks $A_{n x n}$ berupa bilangan rill negatif atau bagian rill bernilai negatif. Jika salah satu atau lebih nilai eigen dari matriks $A_{n x n}$ berupa bilangan rill positif atau bagian rill bernilai positif maka titik kritis tidak stabil. Apabila nilai eigen dari persamaan (3) tidak dapat ditentukan secara langsung maka dapat diterapkan metode Routh-Hurwitz. Kriteria kestabilan Routh-Hurwitz merupakan suatu metode yang dapat menunjukkan kestabilan sistem dengan memperhatikan koefesien dari persamaan karakteristik tanpa menghitung akar-akar karakteristiknya secara langsung.

Tabel 1 : Kriteria Routh-Hurwitz

\begin{tabular}{|c|cccc|}
\hline$\lambda^{n}$ & $a_{n}$ & $a_{n-2}$ & $a_{n-4}$ & $\cdots$ \\
$\lambda^{n-1}$ & $a_{n-1}$ & $a_{n-3}$ & $a_{n-5}$ & $\cdots$ \\
$\lambda^{n-2}$ & $b_{1}$ & $b_{2}$ & $b_{3}$ & $\cdots$ \\
$\lambda^{n-3}$ & $c_{1}$ & $c_{2}$ & $c_{3}$ & $\cdots$ \\
& & & & \\
$\vdots$ & & $\vdots$ & $\vdots$ & \\
$\lambda^{0}$ & & $q$ & $\vdots$ & \\
\hline
\end{tabular}

Sumber: Subiono, 2013 
Jika diberikan persamaan karakteristik berikut:

$p(\lambda)=a_{n} \lambda^{n}+a_{n-1} \lambda^{n-1}+a_{n-2} \lambda^{n-2}+\cdots+a_{1} \lambda+a_{0}$.

Nilai dari $b_{1}, b_{2}, c_{1}$, dan $c_{2}$ diperoleh dari perhitungan sebagai berikut :

$b_{1}=\frac{a_{n-1} a_{n-2}-a_{n} a_{n-3}}{a_{n-1}}, b_{2}=\frac{a_{n-1} a_{n-4}-a_{n} a_{n-5}}{a_{n-1}}, c_{1}=\frac{b_{1} a_{n-3}-b_{2} a_{n-1}}{b_{1}}, c_{2}=\frac{b_{1} a_{n-5}-b_{3} a_{n-1}}{b_{1}}$.

Sistem dikatakan stabil apabila tidak ada perubahan tanda yang terjadi dalam kolom pertama pada tabel Kriteria Routh-Hurwitz yaitu semua bertanda positif atau semua bertanda negatif.

\section{HASIL DAN PEMBAHASAN}

Model dinamika dari pengendalian penyakit embun jelaga pada tanaman cengkeh dibangun berdasarkan fakta-fakta dan asumsi-asumsi yang telah diadaptasi mengikuti model SI (Nugroho, 2009). Terdapat 5 populasi yang diamati yaitu populasi tanaman cengkeh yang terbagi menjadi dua subpopulasi yaitu populasi tanaman cengkeh yang rentan $\left(S_{c}\right)$ dan populasi yang terinfeksi penyakit embun jelaga $\left(I_{c}\right)$, populasi kutu daun (Coccus Viridis Green) $\left(K_{d}\right)$, populasi jamur Capnadium $s p\left(J_{c}\right)$, populasi vektor semut hitam yang dibagi ke dalam dua subpopulasi yaitu populasi semut yang rentan membawa jamur $\left(S_{v}\right)$ dan populasi semut yang telah membawa jamur $\left(I_{v}\right)$, serta populasi predator kumbang helm Cycloneda spp $\left(K_{h}\right)$ sebagai pemangsa hama kutu daun (Coccus Viridis Green).

Pertumbuhan, perpindahan, kematian serta interaksi dari masing-masing populasi yang berperan dalam pengendalian alami penyebaran penyakit embun jelaga tanaman cengkeh dinyatakan dalam diagram transfer pada Gambar 1.

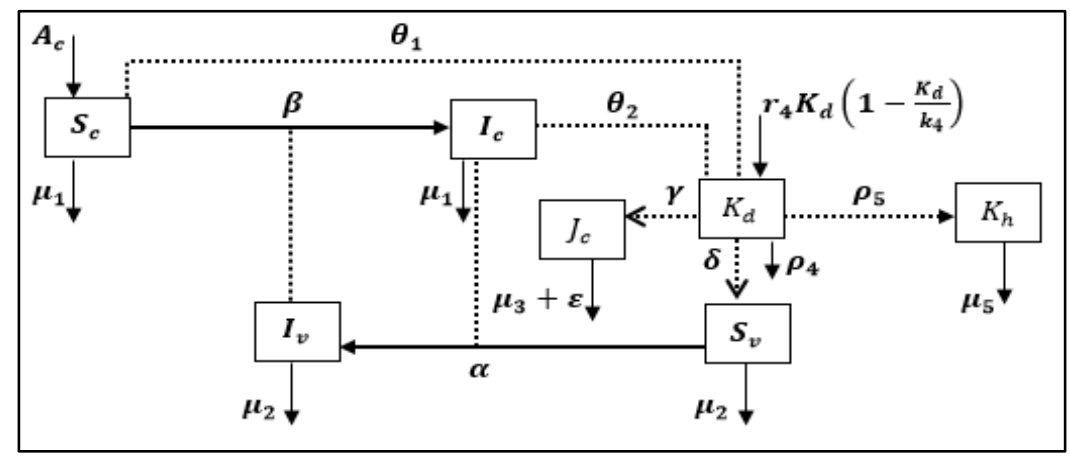

Gambar 1 : Diagram Kompartemen Pengendalian Penyakit Embun Jelaga

Dari diagram tersebut dapat dirumuskan sistem persamaan diferensial untuk model pengendalian alami penyakit embun jelaga sebagai berikut :

$\frac{d S_{c}}{d t}=A_{c}-\mu_{1} S_{c}-\beta \frac{S_{c} I_{v}}{N_{c}}-\theta_{1} \frac{S_{c} K_{d}}{N_{c}}$
$\frac{d I_{c}}{d t}=\beta \frac{S_{c} I_{v}}{N_{c}}-\mu_{1} I_{c}-\theta_{2} \frac{I_{c} K_{d}}{N_{c}}$
$\frac{d S_{v}}{d t}=\delta S_{v} K_{d}-\mu_{2} S_{v}-\alpha \frac{S_{v} I_{c}}{N_{v}}$ 
$\frac{d I_{v}}{d t}=\alpha \frac{S_{v} I_{c}}{N_{v}}-\mu_{2} I_{v}$

$\frac{d J_{c}}{d t}=\gamma J_{c} K_{d}-\varepsilon J_{c}^{2}-\mu_{3} J_{c}$

$\frac{d K_{d}}{d t}=r_{4} K_{d}\left(1-\frac{K_{d}}{k_{4}}\right)-\rho_{4} K_{h} K_{d}$

$\frac{d K_{h}}{d t}=\rho_{5} K_{h} K_{d}-\mu_{5} K_{h}$

Tabel 2 : Deskripsi Parameter

\begin{tabular}{|c|c|c|c|c|}
\hline Parameter & Deskripsi & Nilai & Sumber & Dimensi \\
\hline$A_{c}$ & $\begin{array}{l}\text { Tingkat rekruitmen } \\
\text { tanaman cengkeh }\end{array}$ & 1000 & Asumsi & Populasi \\
\hline$\gamma$ & $\begin{array}{l}\text { Laju pertumbuhan jamur } \\
\text { Capnadium sp akibat } \\
\text { embun madu }\end{array}$ & $\begin{array}{l}\text { Asumsi sesuai } \\
\text { syarat eksis dan } \\
\text { stabil }\end{array}$ & - & Bulan \\
\hline$\delta$ & $\begin{array}{l}\text { Laju pertumbuhan semut } \\
\text { hitam akibat embun madu }\end{array}$ & 0.0015 & Wijaya, 2007 & Bulan \\
\hline$\beta$ & $\begin{array}{l}\text { Laju transisi subpopulasi } \\
\text { cengkeh rentan ke } \\
\text { subpopulasi terinfeksi }\end{array}$ & $\begin{array}{l}\text { Asumsi sesuai } \\
\text { syarat eksis dan } \\
\text { stabil }\end{array}$ & - & Bulan \\
\hline$r_{4}$ & Laju kelahiran konstan & 0.004 & $\begin{array}{l}\text { Rismayani } \\
\text { dkk, } 2013\end{array}$ & Bulan \\
\hline$k_{4}$ & Carryng Capacity & $\begin{array}{l}\text { Asumsi sesuai } \\
\text { syarat eksis dan } \\
\text { stabil }\end{array}$ & - & Populasi \\
\hline$\rho_{5}$ & $\begin{array}{l}\text { Laju pertumbuhan } \\
\text { kumbang helm akibat } \\
\text { memangsa kutu daun }\end{array}$ & 0.004 & $\begin{array}{l}\text { Agus dan } \\
\text { Sudarmaji, } \\
2009\end{array}$ & Bulan \\
\hline$\alpha$ & $\begin{array}{c}\text { Laju transisi dari } \\
\text { subpopulasi semut hitam } \\
\text { bebas jamur ke } \\
\text { subpopulasi pembawa } \\
\text { jamur }\end{array}$ & $\begin{array}{l}\text { Asumsi sesuai } \\
\text { syarat eksis dan } \\
\text { stabil }\end{array}$ & - & Bulan \\
\hline$\theta_{1}$ & $\begin{array}{l}\text { Peluang laju kematian } \\
\text { subpopulasi cengkeh } \\
\text { rentan akibat hama kutu } \\
\text { daun }\end{array}$ & $\begin{array}{l}\text { Asumsi sesuai } \\
\text { syarat eksis dan } \\
\text { stabil }\end{array}$ & - & Bulan \\
\hline$\theta_{2}$ & $\begin{array}{l}\text { Peluang laju kematian } \\
\text { subpopulasi cengkeh }\end{array}$ & $\begin{array}{l}\text { Asumsi sesuai } \\
\text { syarat eksis dan } \\
\text { stabil }\end{array}$ & - & Bulan \\
\hline
\end{tabular}




\begin{tabular}{|c|c|c|c|c|}
\hline & $\begin{array}{c}\text { rentan ke subpopulasi } \\
\text { terinfeksi }\end{array}$ & & & \\
\hline$\rho_{4}$ & $\begin{array}{l}\text { Laju kematian kutu daun } \\
\text { Coccous Viridis Green } \\
\text { akibat dimangsa kumbang } \\
\text { helm Cycloneda spp }\end{array}$ & 0.001 & $\begin{array}{l}\text { Panggalo } \\
\text { dkk, } 2014\end{array}$ & Bulan \\
\hline$\varepsilon$ & $\begin{array}{l}\text { Laju kematian jamur } \\
\text { Capnadium sp akibat } \\
\text { persaingan makanan } \\
\quad \text { (embun madu) }\end{array}$ & $\begin{array}{l}\text { Asumsi sesuai } \\
\text { syarat eksis dan } \\
\text { stabil }\end{array}$ & - & Bulan \\
\hline$\mu_{1}$ & $\begin{array}{l}\text { Laju kematian alami } \\
\text { tanaman cengkeh }\end{array}$ & $\frac{1}{100 \times 12}$ & $\frac{1}{\text { life time }}$ & Bulan \\
\hline$\mu_{2}$ & $\begin{array}{l}\text { Laju kematian alami } \\
\text { vektor semut hitam }\end{array}$ & $\frac{1}{2 \times 12}$ & Wijaya, 2007 & Bulan \\
\hline$\mu_{3}$ & $\begin{array}{l}\text { Laju kematian alami jamur } \\
\text { Capnadium } s p\end{array}$ & $\begin{array}{l}\text { Asumsi sesuai } \\
\text { syarat eksis dan } \\
\text { stabil }\end{array}$ & $\frac{1}{\text { life time }}$ & Bulan \\
\hline$\mu_{5}$ & $\begin{array}{c}\text { Laju kematian alami } \\
\text { kumbang helm Cycloneda } \\
\text { spp }\end{array}$ & 0.2 & $\begin{array}{l}\text { Mawarsih, } \\
2011\end{array}$ & Bulan \\
\hline
\end{tabular}

\subsection{Menentukan Titik Kritis}

Titik kritis dari sistem persamaan (5) - (11) dapat diperoleh dengan memandang sistem sebagai suatu kedaan setimbang, yaitu apabila $\frac{d S_{c}}{d t}=0, \frac{d I_{c}}{d t}=0, \frac{d S_{v}}{d t}=0, \frac{d I_{v}}{d t}=0, \frac{d J_{c}}{d t}=0$, $\frac{d K_{d}}{d t}=0$, dan $\frac{d K_{h}}{d t}=0$. Sehingga menghasilkan 5 titik kritis eksis dengan syarat yang menggambarkan kondisi bebas penyakit sebagai berikut :

$T_{1}=\left(\frac{A_{c}}{\mu_{1}}, 0,0,0,0,0,0\right), T_{5}=\left(\frac{A_{c} N_{c}}{N_{c} \mu_{1}+\theta_{1} k_{4}}, 0,0,0, k_{4}, 0\right), T_{6}=\left(\frac{A_{c} N_{c} \rho_{5}}{N_{c} \mu_{1} \rho_{5}-\theta_{1} \mu_{5}}, 0,0,0,0, \frac{\mu_{5}}{\rho_{5}}, \frac{r_{4}\left(k_{4} \rho_{5}-\mu_{5}\right)}{\rho_{5} \rho_{4} k_{4}}\right)$, $T_{7}=\left(\frac{A_{c} N_{c}}{\mu_{1} N_{c}+\theta_{1} k_{4}}, 0,0,0, \frac{\gamma k_{4}-\mu_{3}}{\varepsilon}, k_{4}, 0\right), T_{8}=\left(\frac{A_{c} N_{c} \rho_{5}}{\mu_{1} N_{c} \rho_{5}+\theta_{1} \mu_{5}}, 0,0,0, \frac{\gamma \mu_{5}-\mu_{3} \rho_{5}}{\varepsilon \rho_{5}}, \frac{\mu_{5}}{\rho_{5}}, \frac{r_{4}\left(k_{4} \rho_{5}-\mu_{5}\right)}{\rho_{5} \rho_{4} k_{4}}\right)$. Adapun

4 titik kritis eksis dengan syarat yang menggambarkan kondisi endemik sebagai berikut :

$T_{9}=\left(\frac{\left(-\mu_{1}\left(k_{4} \delta-\mu_{2}\right) N_{v}+A_{c} \alpha\right)-k_{4} \theta_{2} N_{v}\left(k_{4} \delta-\mu_{2}\right)}{\mu_{1} N_{c}+\theta_{1} k_{4}}, \frac{\left(\delta K_{4}-\mu_{2}\right) N_{v}}{\alpha}, \frac{\mu_{2} N_{v}\left(\mu_{1} N_{c}+\theta_{2} k_{4}\right)\left(\mu_{1} N_{c}+\theta_{1} k_{4}\right)}{\left(-\left(k_{4} \theta_{2}+\mu_{1} N_{c}\right)\left(\delta k_{4}-\mu_{2}\right) N_{v}+A_{c} N_{c} \alpha\right) \beta}\right.$,

$\left.\frac{N_{v}\left(\delta k_{4}-\mu_{2}\right)\left(\mu_{1} N_{c}+\theta_{2} k_{4}\right)\left(\mu_{1} N_{c}+\theta_{1} k_{4}\right)}{\left(-\left(k_{4} \theta_{2}+\mu_{1} N_{c}\right)\left(\delta k_{4}-\mu_{2}\right) N_{v}+A_{c} N_{c} \alpha\right) \beta}, 0, k_{4}, 0\right), T_{10}=\left(\frac{N_{c}\left(N_{v} \mu_{2} \mu_{1}+A_{c} \alpha\right) \rho_{5}^{2}-\mu_{5} N_{v}\left(\delta \mu_{1} N_{c}-\mu_{2} \theta_{2}\right) \rho_{5}-N_{v} \delta \mu_{5}^{2} \theta_{2}}{\left(N_{c} \mu_{1} \rho_{5}+\theta_{1} \mu_{5}\right) \alpha \rho_{5}}\right.$,

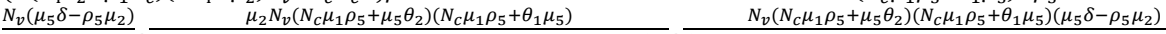

$\frac{\alpha \rho_{5}}{\left(N_{c}\left(N_{v} \mu_{2} \mu_{1}+A_{c} \alpha\right) \rho_{5}^{2}-\mu_{5} N_{v}\left(\delta \mu_{1} N_{c}-\mu_{2} \theta_{2}\right) \rho_{5}-N_{v} \delta \mu_{5}^{2} \theta_{2}\right) \beta}, \overline{\left(N_{c}\left(N_{v} \mu_{2} \mu_{1}+A_{c} \alpha\right) \rho_{5}^{2}-\mu_{5} N_{v}\left(\delta \mu_{1} N_{c}-\mu_{2} \theta_{2}\right) \rho_{5}-N_{v} \delta \mu_{5}^{2} \theta_{2}\right) \rho_{5} \beta}$ $\left., 0, \frac{\mu_{5}}{\rho_{5}}, \frac{r_{4}\left(k_{4} \rho_{5}-\mu_{5}\right)}{\rho_{5} \rho_{4} k_{4}}\right), T_{11}=\left(\frac{\left(-\mu_{1}\left(\delta k_{4}-\mu_{2}\right) N_{v}+\alpha A_{c}\right) N_{c}-k_{4} \theta_{2} N_{v}\left(\delta k_{4}-\mu_{2}\right)}{\left(\mu_{1} N_{c}+\theta_{1} k_{4}\right) \alpha}, \frac{\left(\delta k_{4}-\mu_{2}\right) N_{v}}{\alpha}, \frac{\mu_{2} N_{v}\left(k_{4} \theta_{2}+N_{c} \mu_{1}\right)\left(N_{c} \mu_{1}+\theta_{1} k_{4}\right)}{\left(-\left(k_{4} \theta_{2}+N_{c} \mu_{1}\right)\left(k_{4} \delta-\mu_{2}\right) N_{v}+A_{c} N_{c} \alpha\right) \beta}\right.$,

$\left., \frac{N_{v}\left(k_{4} \theta_{2}+N_{c} \mu_{1}\right)\left(N_{c} \mu_{1}+\theta_{1} k_{4}\right)\left(k_{4} \delta-\mu_{2}\right)}{\left(-\left(k_{4} \theta_{2}+N_{c} \mu_{1}\right)\left(k_{4} \delta-\mu_{2}\right) N_{v}+A_{c} N_{c} \alpha\right) \beta}, \frac{\gamma k_{4}-\mu_{3}}{\varepsilon}, k_{4}, 0\right), T_{12}=$ $\left(\frac{N_{c}\left(N_{v} \mu_{2} \mu_{1}+A_{c} \alpha\right) \rho_{5}^{2}-\mu_{5} N_{v}\left(\delta \mu_{1} N_{c}-\mu_{2} \theta_{2}\right) \rho_{5}-N_{v} \delta \mu_{5}^{2} \theta_{2}}{\left(N_{c} \mu_{1} \rho_{5}+\theta_{1} \mu_{5}\right) \alpha \rho_{5}}\right.$, 
$\frac{N_{v}\left(\mu_{5} \delta-\rho_{5} \mu_{2}\right)}{\alpha \rho_{5}}, \frac{\mu_{2} N_{v}\left(N_{c} \mu_{1} \rho_{5}+\mu_{5} \theta_{2}\right)\left(N_{c} \mu_{1} \rho_{5}+\theta_{1} \mu_{5}\right)}{\beta\left(N_{c}\left(N_{v} \mu_{2} \mu_{1}+A_{c} \alpha\right) \rho_{5}^{2}-\mu_{5} N_{v}\left(\delta \mu_{1} N_{c}-\mu_{2} \theta_{2}\right) \rho_{5}-N_{v} \delta \mu_{5}^{2} \theta_{2}\right)}, \frac{N_{v} N_{c} \mu_{1}\left(\mu_{5} \delta-\rho_{5} \mu_{2}\right) \rho_{5}+N_{v} \theta_{2} \mu_{5}\left(\mu_{5} \delta-\rho_{5} \mu_{2}\right)}{\alpha S_{c} \rho_{5}^{2} \beta}, \frac{\gamma \mu_{5}-\mu_{3} \rho_{5}}{\rho_{5} \varepsilon}$, $\left.\frac{\mu_{5}}{\rho_{5}}, \frac{r_{4}\left(k_{4} \rho_{5}-\mu_{5}\right)}{\rho_{5} \rho_{4} k_{4}}\right)$.

Titik kritis $T_{1}, T_{5}, T_{6}, T_{7}$ dan $T_{8}$ menggambarkan kondisi bebas penyakit karena tidak terdapat subpopulasi cengkeh terinfeksi dan subpopulasi semut pembawa jamur Capnadium $s p$ yaitu $I_{c}^{*}=0$ dan $I_{v}^{*}=0$. Sementara titik kritis kondisi endemik terdapat subpopulasi cengkeh terinfeksi $\left(I_{c}^{*} \neq 0\right)$ dan subpopulasi semut pembawa jamur Capnadium $s p\left(I_{v}^{*} \neq 0\right)$. Untuk titik kritis $T_{6}$ sampai $T_{12}$ merupakan titik kritis yang dapat dijamin keeksistensiannya dengan memberikan syarat eksis sebagai berikut :

$k_{4}>\sup \left\{\frac{\mu_{5}}{\rho_{5}}, \frac{\mu_{3}}{\gamma}, \frac{\mu_{2}}{\delta}\right\} \quad$ dan $\quad \frac{\rho_{5}}{\mu_{5}}<\inf \left\{\frac{\gamma}{\mu_{3}}, \frac{\delta}{\mu_{2}}\right\}$ dan $\quad A_{C}>$ $\sup \left\{\frac{\left(k_{4} \delta-\mu_{2}\right)\left(k_{4} \theta_{2}+\mu_{1} N_{c}\right) N_{v}}{N_{c} \alpha}, \frac{N_{v}\left(\mu_{1} N_{c} \rho_{5}+\mu_{5} \theta_{2}\right)\left(-\rho_{5} \mu_{2}+\mu_{5} \delta\right)}{N_{c} \rho_{5}^{2} \alpha}\right\}$.

\subsection{Analisis Kestabilan Titik Kritis}

Dengan melakukan lineariasi terhadap model matematika pengendalian alami penyakit embun jelaga di masing-masing titik kritis yang eksis diperoleh titik kritis $T_{1}, T_{5}, T_{6}, T_{7}$ dan $T_{8}$ adalah titik kritis yang stabil menggunakan syarat dan memenuhi kriteria Routh-Hurwitz. Untuk titik kritis kondisi endemik yaitu $T_{9}, T_{10}, T_{11}$ dan $T_{12}$ merupakan titik kritis yang tidak stabil karena tidak memenuhi kriteria Routh-Hurwitz. Syarat kestabilan dari titik kritis yang menggambarkan kondisi bebas penyakit dapat dilihat pada Tabel 3 .

Tabel 3 : Syarat Kestabilan

\begin{tabular}{|c|c|c|}
\hline Titik Kritis & Syarat Kestabilan & Keterangan \\
\hline$T_{5}$ & $\delta<\frac{\mu_{2}}{k_{4}}, \rho_{5}<\frac{\mu_{5}}{k_{4}}$ dan $\gamma<\frac{\mu_{3}}{k_{4}}$ & Stabil \\
\hline$T_{6}$ & $\frac{\delta}{\rho_{5}}<\frac{\mu_{2}}{\mu_{5}} \operatorname{dan} \frac{\gamma}{\rho_{5}}<\frac{\mu_{3}}{\mu_{5}}$ & Stabil \\
\hline$T_{7}$ & $\delta<\frac{\mu_{2}}{k_{4}} \operatorname{dan} \rho_{5}<\frac{\mu_{5}}{k_{4}}$ & Stabil \\
\hline$T_{8}$ & $\frac{\delta}{\rho_{5}}<\frac{\mu_{2}}{\mu_{5}}$ & Stabil \\
\hline
\end{tabular}

\subsection{Simulasi Titik Kritis}

Simulasi dari dinamika pengendalian alami penyakit embun jelaga pada tanaman cengkeh dapat dilakukan dengan memberikan nilai-nilai parameter yang memenuhi syarat eksistensi dan syarat stabil dari titik kritis. Tabel 2 merupakan nilai parameter yang digunakan untuk melakukan simulasi. Simulasi dari dinamika pengendalian alami penyakit embun jelaga pada tanaman cengkeh juga dilakukan dengan memberikan nilai awal untuk semua variabel terhadap masing-masing titik kritis yang digunakan untuk menggambarkan kurva-kurva pada simulasi. 
Gambar 2 merupakan simulasi titik kritis $T_{1}$ yang menggambarkan kondisi bebas penyakit. Parameter yang digunakan sesuai syarat eksis dan stabil untuk titik kritis $T_{1}$ yaitu $\gamma=0.0037, \beta=0.000032, k_{4}=2000, \alpha=0.9, \theta_{1}=0.071, \theta_{2}=0.929, \varepsilon=0.0714, \mu_{3}=\frac{1}{21}$. Grafik simulasi menginterprestasikan pertumbuhan subpopulasi cengkeh rentan yang terus meningkat seiring semakin bertambahnya waktu. Hal ini disebabkan karena menurunnya populasi-populasi penghambat pertumbuhan subpopulasi cengkeh rentan tersebut, seperti populasi hama kutu daun Coccus Viridis Green dan populasi jamur Capnadium $s p$ dari banyaknya populasi awal yang diberikan pada saat $t=0$, serta menurunnya subpopulasi vektor semut hitam sebagai penyebar penyakit embun jelaga.

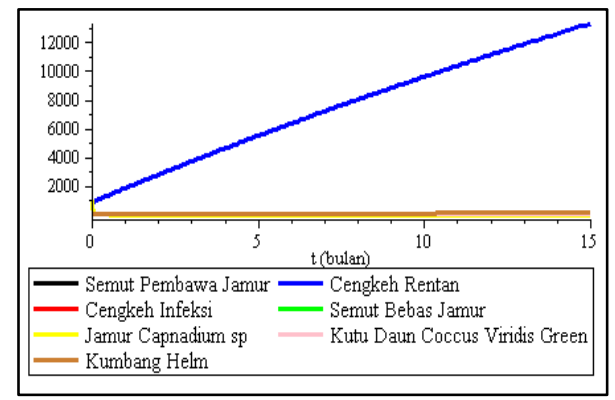

Gambar 2 : Kurva Simulasi Titik Kritis $T_{1}$

Gambar 3 merupakan simulasi titik kritis $T_{5}$ yang mengggambarkan kondisi bebas penyakit. Parameter yang digunakan sesuai syarat eksis dan stabil untuk titik kritis $T_{5}$ yaitu $\gamma=0.00028, \beta=0.073, k_{4}=2500, \alpha=0.048, \theta_{1}=0.50, \theta_{2}=0.50, \varepsilon=0.0099, \mu_{3}=0.011$. Grafik simulasi merepresentasikan pertumbuhan subpopulasi cengkeh rentan yang meningkat dan selanjutnya subpopulasi tersebut berjumlah tetap akibat eksistensi populasi hama kutu daun Coccus Viridis Green yang mengakibatkan sebagian anggota subpopulasi ini mengalami kematian karena serangannya. Simulasi memperlihatkan subpopulasi cengkeh terinfeksi mengalami penurunan jumlah subpopulasi disebabkan karena menurunnya jumlah populasi jamur Capnadium sp dan semut hitam.

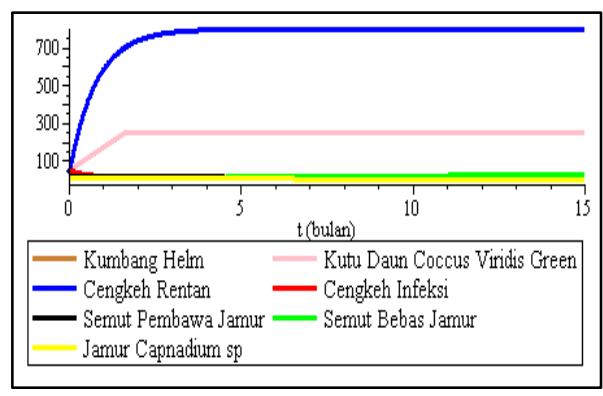

Gambar 3 : Kurva Simulasi Titik Kritis $T_{5}$ 
Gambar 4 merupakan simulasi titik kritis $T_{6}$ yang menggambarkan kondisi bebas penyakit. Parameter yang digunakan sesuai syarat eksis dan stabil untuk titik kritis $T_{6}$ yaitu $\gamma=0.00028, \beta=0.073, k_{4}=2500, \alpha=0.048, \theta_{1}=0.71, \theta_{2}=0.29, \varepsilon=0.0099, \mu_{3}=\frac{1}{900}$. Grafik simulasi merepresentasikan pertumbuhan subpopulasi cengkeh rentan kemudian berjumlah tetap akibat eksistensi populasi hama kutu daun Coccus Viridis Green. Eksistensi populasi kumbang helm Cycloneda spp sebagai predator mampu menekan jumlah subpopulasi hama kutu daun Coccus Viridis Green. Simulasi memperlihatkan subpopulasi cengkeh terinfeksi mengalami penurunan jumlah subpopulasi disebabkan karena menurunnya jumlah populasi jamur Capnadium sp dan menurunnya pula jumlah subpopulasi semut hitam.

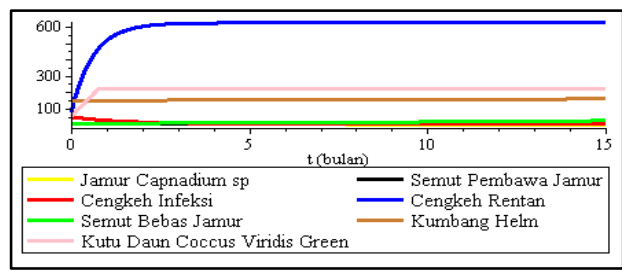

Gambar 4 : Kurva Simulasi Titik Kritis $T_{6}$

Gambar 5 merupakan simulasi titik kritis $T_{7}$ yang menggambarkan kondisi bebas penyakit. Parameter yang digunakan sesuai syarat eksis dan stabil untuk titik kritis $T_{7}$ yaitu $\gamma=0.0028, \beta=0.789, k_{4}=2500, \alpha=0.048, \theta_{1}=0.50, \theta_{2}=0.50, \varepsilon=0.0011, \mu_{3}=\frac{1}{90}$. Grafik simulasi merepresentasikan pertumbuhan subpopulasi cengkeh rentan yang meningkat dan kemudian berjumlah tetap akibat eksistensi populasi hama kutu daun Coccus Viridis Green dan masih mampu menahan eksistensi populasi jamur Capnadium $s p$ dengan pertumbuhan hingga mencapai 550 individu dalam kurun waktu 13 bulan. Simulasi memperlihatkan subpopulasi cengkeh terinfeksi mengalami penurunan jumlah subpopulasi akibat menurunnya jumlah subpopulasi semut hitam pembawa jamur.

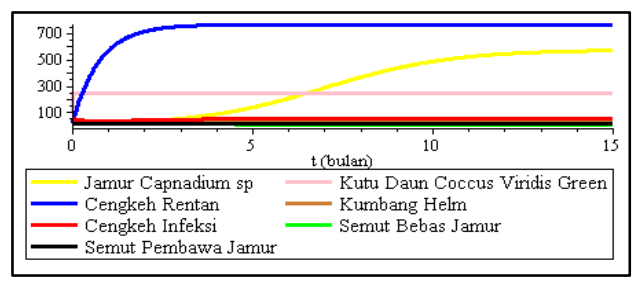

Gambar 5 : Kurva Simulasi Titik Kritis $T_{7}$

Gambar 6 merupakan simulasi titik kritis $T_{8}$ yang menggambarkan kondisi bebas penyakit. Parameter yang digunakan sesuai syarat eksis dan stabil untuk titik kritis $T_{8}$ yaitu $\gamma=0.00028, \beta=0.073, k_{4}=2500, \alpha=0.048, \theta_{1}=0.71, \theta_{2}=0.29, \varepsilon=0.00011, \mu_{3}=\frac{1}{21}$. Grafik simulasi merepresentasikan pertumbuhan subpopulasi cengkeh rentan yang meningkat kemudian berjumlah tetap akibat eksistensi populasi hama kutu daun Coccus Viridis Green. Eksistensi populasi kumbang helm Cycloneda spp sebagai predator mampu menahan laju 
pertumbuhan populasi hama kutu daun Coccous Viridis Green. Simulasi memperlihatkan subpopulasi cengkeh terinfeksi mengalami penurunan jumlah subpopulasi yang disebabkan karena tetapnya jumlah populasi jamur Capnadium $s p$ sebagai penginfeksi dan menurunnya pula jumlah subpopulasi semut hitam.

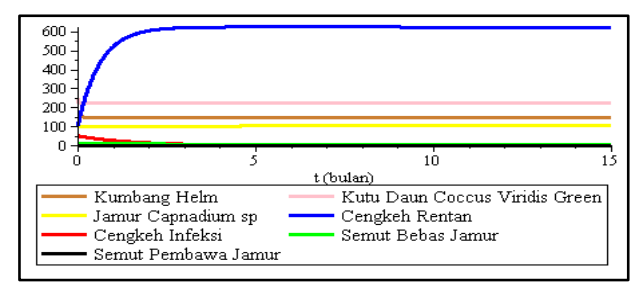

Gambar 6 : Kurva Simulasi Titiik Kritis $T_{8}$

Gambar 7 merupakan simulasi titik kritis $T_{9}$ yang menggambarkan kondisi endemik. Parameter yang digunakan sesuai syarat eksis dan stabil untuk titik kritis $T_{9}$ yaitu $\gamma=0.00028, \beta=0.073, k_{4}=500, \alpha=0.48, \theta_{1}=0.5, \theta_{2}=0.5, \varepsilon=0.0099, \mu_{3}=\frac{1}{90}$. Grafik simulasi menginterprestasikan pertumbuhan subpopulasi cengkeh rentan yang mengalami penurunan jumlah subpopulasi disebabkan oleh pertumbuhan subpopulasi semut pembawa jamur penginfeksi yang mengalami peningkatan jumlah subpopulasi dan eksistensi populasi hama kutu daun Coccous Viridis Green. Selanjutnya subpopulasi cengkeh rentan mengalami peningkatan kembali yang diakibatkan karena menurunnya jumlah subpopulasi vektor semut hitam.

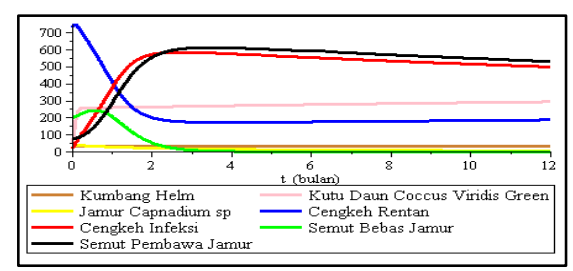

Gambar 7 : Kurva Simulasi Titik Kritis $T_{9}$

Gambar 8 merupakan simulasi titik kritis $T_{10}$ yang menggambarkan kondisi endemik. Parameter yang digunakan sesuai syarat eksis dan stabil untuk titik kritis $T_{10}$ yaitu $\gamma=0.00028, \beta=0.073, k_{4}=500, \alpha=0.49, \theta_{1}=0.5, \theta_{2}=0.5, \varepsilon=0.0099, \mu_{3}=\frac{1}{10}$. Grafik simulasi menginterprestasikan pertumbuhan subpopulasi cengkeh rentan yang mengalami peningkatan jumlah subpopulasi kemudian mengalami penurunan jumlah subpopulasi yang disebabkan oleh eksistensi populasi hama kutu daun Coccous Viridis Green yang juga mengalami penurunan jumlah populasi akibat keberadaan populasi kumbang helm Cycloneda spp sebagai predator yang terus bertambah. Sehingga subpopulasi cengkeh rentan mengalami peningkatan jumlah subpopulasi kembali setelah melewati waktu 8 bulan. 

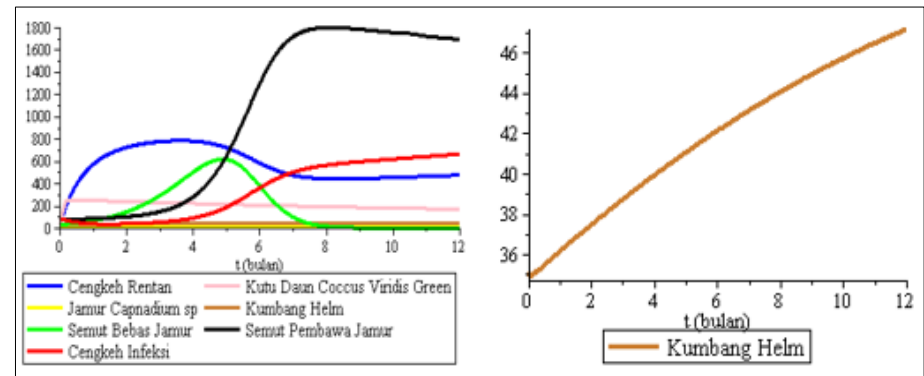

Gambar 8 : Kurva Simulasi Titik Kritis $T_{10}$

Gambar 9 merupakan simulasi titik kritis $T_{11}$ yang menggambarkan kondisi endemik. Parameter yang digunakan sesuai syarat eksis dan stabil untuk titik kritis $T_{11}$ yaitu $\gamma=0.0028, \beta=0.73, k_{4}=500, \alpha=0.48, \theta_{1}=0.5, \theta_{2}=0.5, \varepsilon=0.0011, \mu_{3}=\frac{1}{9} . \quad$ Grafik simulasi menginterprestasikan pertumbuhan subpopulasi cengkeh rentan yang mengalami peningkatan jumlah subpopulasi. Selanjutnya subpopulasi tersebut mengalami penurunan jumlah subpopulasi yang disebabkan oleh eksistensi populasi jamur Capnadium sp sebagai penginfeksi yang terus mengalami pertambahan jumlah populasi seiring dengan bertambahnya waktu yang didukung oleh vektor semut hitam dalam penyebarannya. Selain itu, eksistensi populasi kutu daun Coccous Viridis Green juga mampu menurunkan jumlah subpopulasi cengkeh rentan akibat serangannya sebagai hama.

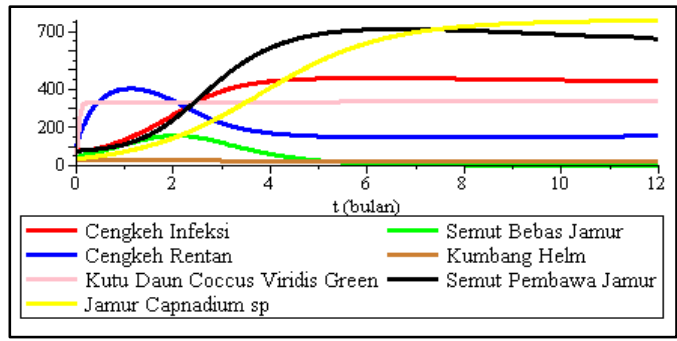

Gambar 9 : Kurva Simulasi Titik Kritis $T_{11}$

Gambar 10 merupakan simulasi titik kritis $T_{12}$ yang menggambarkan kondisi endemik. Parameter yang digunakan sesuai syarat eksis dan stabil untuk titik kritis $T_{12}$ yaitu $\gamma=0.00028, \beta=0.073, k_{4}=500, \alpha=0.49, \theta_{1}=0.5, \theta_{2}=0.5, \varepsilon=0.0001, \mu_{3}=\frac{1}{10}$. Grafik simulasi menginterprestasikan pertumbuhan subpopulasi cengkeh rentan yang mengalami peningkatan jumlah subpopulasi selanjutnya mengalami penurunan jumlah subpopulasi yang disebabkan oleh eksistensi populasi hama kutu daun Coccous Viridis Green dengan pertumbuhan yang terus mengalami penurunan jumlah populasi akibat keberadaan populasi kumbang helm Cycloneda spp sebagai predator. Sehingga subpopulasi cengkeh rentan mengalami pertambahan jumlah subpopulasi kembali setelah melewati waktu 8 bulan. 


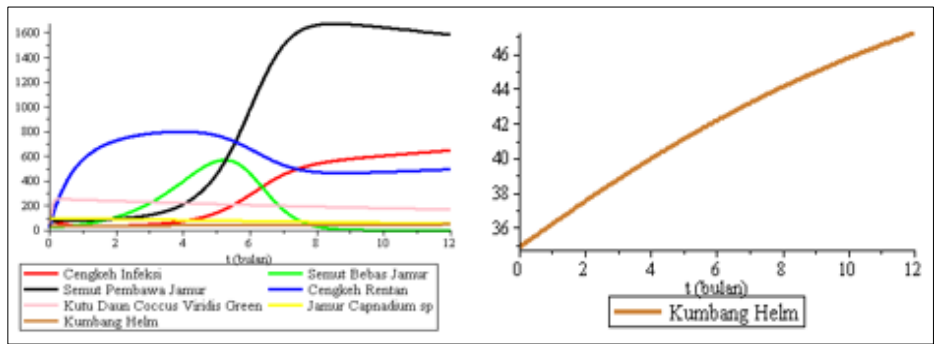

Gambar 10 : Kurva Simulasi Titik Kritis $T_{12}$

\section{KESIMPULAN}

Penelitian ini telah mengkonstruksi model matematika dari pengendalian alami penyakit embun jelaga. Dari model matematika tersebut diperoleh 9 titik kritis yang dapat dijamin eksistensinya. Hasil uji kestabilan pada titik kritis dapat diketahui bahwa titik kritis bebas penyakit dapat menjadi stabil dengan menjamin beberapa titik kritis yang lain agar tidak eksis.

Sementara titik kritis endemik yang diperoleh adalah titik kritis yang tidak stabil sehingga memberikan peluang untuk menambahkan desain kontrol dengan metoda yang berbeda untuk mengendalikan penyebaran penyakit ini. Simulasi titik kritis yang menggambarkan kondisi endemik pada hasil penelitian menunjukkan bahwa eksistensi populasi kumbang helm Cycloneda spp sebagai predator mampu mengendalikan penyebaran penyakit dengan cara menekan laju pertumbuhan populasi hama kutu daun Coccous Viridis Green sehingga menyebabkan terhambatnya pertumbuhan populasi jamur Capnadium sp sebagai penginfeksi akibat berkurangnya embun madu / sumber makanan yang hanya dapat dihasilkan oleh populasi hama kutu daun melalui kotorannya.

\section{DAFTAR PUSTAKA}

[1]. Anton H., Aljabar Linear Elementer Edisi ke-5 Terjemahan Pantur Silaban \& I Nyoman Susila, Erlangga, 1992, Jakarta.

[2]. Ernawati, F., dan Yuniarti, F., Mewaspadai Embun Jelaga pada Tanaman Cengkeh, Balai Besar Perbenihan dan Proteksi Tanaman Perkebunan Surabaya, 2014, Surabaya.

[3]. Indriati, G., Khaerati., Soesanty F., Pengendalian Hama Terpadu Hama Penggerek Cengkeh, Sinar tani Rubrik Agroinovasi : 9-12, Balai Penelitian Tanaman Rempah dan Aneka Tanaman Industri, 2011, http://www.litbang.pertanian.go.id/download/one/86/.

[4]. Mariana, L., Skripsi : Hama Dan Penyakit Cengkeh Di Wilayah Kabupaten Kediri Jawa Timur, Fakultas Pertanian Institut Pertanian Bogor (IPB), 2013, Bogor, http://repository.ipb.ac.id/handle/123456789/67570. 
[5]. Mawarsih., Skripsi : Kelimpahan dan Keanekaragaman Kumbang Tinja (Coleptera : Scarabaeidae) di Kawasan Taman Wisata Pulau Situ Gintung Tangerang Banten, Universitas Islam Negeri Syarif Hidayatullah, 2011, Jakarta.

[6]. Nugroho, Susilo., Skripsi : Pengaruh Vaksinasi Terhadap Penyebaran Penyakit dengan Model Endemik SIR, Universitas 11 Maret, 2009, Surabaya.

[7]. Panggalo, N. A., Yunus, M., Khasanah, N., Jurnal : Inventarisasi Predator Hama Helopeltis spp. (Hemiptera : Miridae) Pada Tanaman Kakao (Theobroma Cacao. L) Di Kecamatan Palolo Kabupaten Sigi, Fakultas Pertanian Universitas Tadulako, 2014, Palu.

[8]. Rismayani, Rubiyo, Ibrahim, M.S.D., Dinamika Populasi Kutu Tempurung (Coccus Viridis Green) dan Kutu Daun (Aphis Gossyippi) Pada Tiga Varietas Kopi Arabika (Coffea Arabica), Balai Tanaman Industri dan Penyegar Sukabumi, Pusat Penelitian dan Pengembangan Perkebunan Bogor, 2013, Bogor.

[9]. Subiono, Sistem Linear dan Kontrol Optimal, Institut Teknologi Sepuluh Nopember, 2013, Surabaya. 